Article

\title{
Development of a Stainless Austenitic Nitrogen-Alloyed CrMnNiMo Spring Steel
}

\author{
Christina Schröder *, Marco Wendler, Thilo Kreschel, Olena Volkova and Andreas Weiß \\ Institute of Iron and Steel Technology, TU Bergakademie Freiberg (TU BAF), 09599 Freiberg, Germany \\ * Correspondence: Christina.Schroeder@iest.tu-freiberg.de
}

Received: 24 July 2019; Accepted: 27 August 2019; Published: 31 August 2019

check for updates

\begin{abstract}
The generation of a nickel-reduced, stainless spring steel strip with a thickness of $0.2 \mathrm{~mm}$, producible under industrial conditions, is the aim of a transfer project together with the Institute of Metal Forming/TU BAF and the Auerhammer Metallwerk GmbH within the DFG Collaborative Research Centre (CRC) 799. The spring steel strip should exhibit a tensile strength of $\geq 1700 \mathrm{MPa}$ in work-hardened and partitioned state. The mechanical and corrosive properties of the steel strip should be equal or better than those given for 1.4310 steel (AISI 301). The article presents the results of laboratory alloys focused on the design of steel strips, which meet the requirements for a cost-effective production. The results presented relate to steel design, microstructure formation, temperature-dependent mechanical properties, and corrosion resistance. Four alloys of the type X5CrMnNiMoN16-X-4 with manganese contents of approximately 2 to $6 \mathrm{wt}$--percent were investigated. The austenitic steel X5CrMnNiMoN16-4-4 with TRIP/TWIP effect was selected for deformation and partitioning treatments. Its deformation-induced $\alpha^{\prime}$-martensite formation significantly contributes to the work hardening of the steel. A short-time annealing treatment (partitioning) further increases the strength properties.
\end{abstract}

Keywords: stainless austenitic spring steel; CrMnNi-steel; deformation-induced $\alpha^{\prime}$-martensite; TRIP/TWIP effect; deformation and partitioning treatment; passivation; corrosion resistance; pitting corrosion

\section{Introduction}

The European standard EN 10151 contains stainless spring steel strips, their treatment and properties [1]. These spring steels are relatively unstable austenitic steels with $\mathrm{M}_{\mathrm{s}}{ }^{{ }^{\prime}}$-temperatures near and below room temperature (RT). The required high-strength properties are achieved by a mainly martensitic microstructure, which is created by appropriate cold forming and subsequent tempering. As a result of the treatment, carbide precipitates are preferentially formed in the martensite and the residual stresses are relieved [2-4]. The strain-hardened and tempered martensitic structure guarantees the required high-strength properties. $\delta$-ferrite fractions of $<2 \%$ are tolerated. Stainless spring steels are classified as corrosion-resistant steels due to their chromium content of more than $12 \%$. Additives of molybdenum and nitrogen improve the corrosion properties and increase the resistance to pitting corrosion [5].

As springs are stressed in the elastic region, high demands are placed on the elastic limit and tensile strength of spring steel, while at the same time low demands are placed on toughness. In the work-hardened condition $+\mathrm{C} 1700$, for example, tensile strengths of 1700 to $1900 \mathrm{MPa}$ at total elongations of $\geq 2 \%$ are required for $0.2 \mathrm{~mm}$ thick spring steel strip of the most common used spring steel 1.4310 (X10CrNi18-8; AISI 301). When stainless steel springs are exposed to corrosion, they must meet special corrosion requirements depending on the application. 
The cost-effective production of high-strength spring steel strip depends mainly on the type of spring steel and its alloy content. In this context, it must be examined to what extent the nickel content of conventional spring steels can be reduced and partially replaced by manganese and nitrogen. In contrast to nickel, nitrogen increases strength strongly [6,7]. In recent years, extensive research, including studies in the CRC 799 "TRIP-Matrix-Composite", has shown that reduced nickel contents reduce the austenite stability and thus promote the formation of $\alpha^{\prime}$-martensite [8-11]. Increasing nitrogen and manganese contents increase the austenite stability and suppress the formation of $\alpha^{\prime}$-martensite [12,13]. This is expressed, for example, by the corresponding effective factors in the calculation of martensitic transformation temperatures or the nickel equivalent in the Schaeffler diagram [14-17]. One objective of the present study is to produce a spring steel with a reduced nickel content by approximately $48 \%$ compared to the conventional $\mathrm{Cr}-\mathrm{Ni}$ spring steel 1.4310 on a laboratory scale. The nickel reduction is compensated by the addition of varying manganese contents and constant nitrogen content. Thereby, the mechanical and corrosive properties must be guaranteed or improved compared to those of spring steel 1.4310. In addition, the study contains results from temperature-dependent tensile tests. From these results, conclusions can be drawn on the selection of an alloy composition suitable for cold forming. In this context, in order to achieve the required mechanical and corrosive properties, it is important to determine the necessary fractions of $\alpha^{\prime}$-martensite in the spring steel. For this purpose, the forming conditions must be adapted to the chemical composition of the steel. Our research partners have already published the production of the $0.2 \mathrm{~mm}$ spring steel strip, in particular hot forming, in separate articles $[18,19]$.

Above all, the choice of suitable forming conditions in the final forming stage is of decisive importance. Our own research results have shown that the effects of the transformation-induced and twinning-induced plasticity (TRIP/TWIP) can be technically exploited to improve the cold forming capacity of austenitic Cr-Ni steels [20,21]. This behavior occurs in steels with low stacking fault energies $\left(\gamma_{\mathrm{SFE}}\right)$ in the range between 15 and $40 \mathrm{mJm}^{-2}$. Almost independently of the type of cold forming process, the highest cold forming capacity is measured in a temperature range in which approximately $22 \%$ deformation-induced $\alpha^{\prime}$-martensite is formed after maximum stress [22]. Under compressive stress, as is the case during rolling, $\alpha^{\prime}$-martensite formation is less favored compared to tensile stress under comparable forming conditions. This contrasts with the fact that multi-axial loading promotes the formation of $\alpha^{\prime}$-martensite to a greater extent than uniaxial tensile stress [3,23]. During the production of cold rolled strip, higher $\alpha^{\prime}$-martensite fractions may occur than after tensile loading. This results in higher strength properties in cold rolled strip compared to tensile test specimens. The preliminary tests on tensile specimens were carried out with this fact in mind. Temperature-dependent tensile tests are less complex than cold rolling tests and also have the advantage of demonstrating the relationship between martensitic formation behavior and the TRIP/TWIP effect. The TRIP/TWIP effect is shown in the tensile test, e.g., in an anomaly of the maximum uniform elongation or strain to failure as a function of temperature. There is a temperature range with maximum plastic elongation $[24,25]$. In conclusion, it can be deduced that a similar temperature range also exists during cold rolling. The knowledge of such a temperature range is of great importance for determining the best possible forming conditions in the spring strip manufacturing process [26]. This can generate savings in forming stages and intermediate annealing. Important conclusions can be drawn from the results of the temperature-dependent tensile tests.

There is also research potential on the extent to which conventional annealing treatment of the work-hardened spring strip can be replaced by short-term annealing (Deformation and Partitioning treatment). The advanced D\&P treatment for austenitic steels has been introduced on the basis of the quenching and partitioning treatment $[13,27]$. Both heat treatments require a $\alpha^{\prime}$-martensitic structure. In contrast to Q\&P treatment, $\alpha^{\prime}$-martensite in austenitic spring steels is not produced by cooling but by deformation. The annealing treatment leads to the formation of nanometre-sized precipitates in the $\alpha^{\prime}$-forming martensite [28]. This is accompanied by precipitation hardening, which causes an increase in strength and counteracts the recovery effects [29]. In addition, carbon and nitrogen accumulate at 
the austenite/martensite phase boundaries as a result of diffusion (Partitioning). Consequently the austenite is stabilized. The D\&P treatment is not yet state of the art in industrial spring band production.

\section{Materials and Methods}

The experimental investigations were preceded by thermodynamic calculations to determine the austenite stability against the formation of $\delta$-ferrite, $\alpha^{\prime}$ - and $\varepsilon$-martensite in austenitic $\mathrm{CrMnNiMoN}$ alloys. For selected alloys the temperature and concentration dependent free enthalpy differences $\Delta \mathrm{G}$ $\gamma \rightarrow \varepsilon$ and $\Delta G \gamma \rightarrow \alpha^{\prime}$ for the $\varepsilon$ - and $\alpha^{\prime}$-martensite formation were determined by ThermoCalc software using the database TCFe8. In addition, the $\mathrm{M}_{\mathrm{s}}{ }^{{ }^{\prime}}$-temperatures (1) according Eichelmann and Hull [14] and the stacking fault energies of the austenites $\gamma_{\mathrm{SFE}}$ (2) [30] were calculated.

The influence of varying manganese contents is of decisive interest.

$$
\begin{aligned}
\mathrm{M}_{\mathrm{s}}{ }^{\alpha^{\prime}}\left({ }^{\circ} \mathrm{C}\right)= & 1305-1665 \cdot(\mathrm{wt}-\% \mathrm{C}+\mathrm{wt}-\% \mathrm{~N})-28 \cdot \mathrm{wt}-\% \mathrm{Si}-33 \cdot \mathrm{wt}-\% \mathrm{Mn}-42 \cdot \mathrm{wt}-\% \mathrm{Cr}-61 \cdot \mathrm{wt}-\% \mathrm{Ni} \\
\gamma_{\mathrm{SFE}}\left(\mathrm{mJ} / \mathrm{m}^{2}\right)= & 39+1.59 \cdot \mathrm{wt}-\% \mathrm{Ni}-1.34 \cdot \mathrm{wt}-\% \mathrm{Mn}+0.06 \cdot(\mathrm{wt}-\% \mathrm{Mn})^{2}-1.75 \cdot \mathrm{wt}-\% \mathrm{Cr} \\
& +0.01 \cdot(\mathrm{wt}-\% \mathrm{Cr})^{2}+15.21 \cdot \mathrm{wt}-\% \mathrm{Mo}-5.59 \cdot \mathrm{wt}-\% \mathrm{Si}+26.27 \cdot(\mathrm{wt}-\% \mathrm{C} \\
& +1.2 \cdot \mathrm{wt}-\% \mathrm{~N}) \cdot(\mathrm{wt}-\% \mathrm{Cr}+\mathrm{wt}-\% \mathrm{Mn}+\mathrm{wt}-\% \mathrm{Mo})^{1 / 2} \\
& +0.61 \cdot[\mathrm{wt}-\% \mathrm{Ni} \cdot(\mathrm{wt}-\% \mathrm{Cr}+\mathrm{wt}-\% \mathrm{Mn})]^{1 / 2}-60.69 \cdot(\mathrm{wt}-\% \mathrm{C}+1.2 \cdot \mathrm{wt}-\% \mathrm{~N})^{1 / 2}
\end{aligned}
$$

On the basis of these results, four austenitic, nickel-reduced CrMnNiMoN steels with manganese contents of $2.4 \%$ to $6 \%$ and a constant nitrogen and molybdenum content of approximately $0.175 \%$ and $0.6 \%$ respectively were melted, alloyed and cast in the laboratory vacuum induction melting and casting furnace VIM 12. The alloys were cast in two water-cooled copper molds in a rise casting process into ingots with a volume of $(80 \times 80 \times 300) \mathrm{mm}^{3}$. The chemical composition of the laboratory steels was determined by spark emission spectrometry, combustion and carrier gas method and is shown in Table 1.

Table 1. Chemical composition of laboratory steels and CrNi steel X10CrNi18-8 (wt.-\%) including its nickel and chromium equivalents $\left(\mathrm{Ni}_{\mathrm{eq}}, \mathrm{Cr}_{\mathrm{eq}}\right)$, the $\mathrm{M}_{\mathrm{s}}{ }^{{ }^{\prime}}$-temperatures and the stacking fault energies $\gamma_{\mathrm{SFE}}$.

\begin{tabular}{cccccccccccc}
\hline Steel & $\mathbf{C r}$ & $\mathbf{M n}$ & $\mathbf{N i}$ & $\mathbf{S i}$ & $\mathbf{C}$ & $\mathbf{N}$ & $\mathbf{M o}$ & $\mathbf{N i}_{\text {eq }}$ & $\mathbf{C r}_{\mathbf{e q}}$ & $\begin{array}{c}\mathbf{M}_{\mathbf{s}} \boldsymbol{\alpha}^{\prime} \\
{\left[{ }^{\circ} \mathbf{C}\right]}\end{array}$ & $\begin{array}{c}\gamma_{\mathbf{S F E}} \\
{\left[\mathbf{m J m}^{-2}\right]}\end{array}$ \\
\hline 1.4310 & 18.1 & 0.91 & 7.73 & 0.36 & 0.08 & 0.035 & 0.26 & 11.3 & 19.1 & -159 & 24.0 \\
$6 \mathrm{Mn}$ & 17.00 & 5.97 & 4.12 & 0.34 & 0.05 & 0.174 & 0.55 & 11.8 & 18.1 & -244 & 27.6 \\
$5 \mathrm{Mn}$ & 16.40 & 5.03 & 4.02 & 0.34 & 0.05 & 0.172 & 0.57 & 11.2 & 17.5 & -176 & 27.5 \\
$4 \mathrm{Mn}$ & 16.50 & 4.02 & 4.08 & 0.33 & 0.05 & 0.182 & 0.59 & 10.9 & 17.6 & -165 & 28.6 \\
$2 \mathrm{Mn}$ & 16.30 & 2.36 & 3.98 & 0.14 & 0.05 & 0.173 & 0.59 & 9.7 & 17.1 & -73 & 28.9 \\
\hline
\end{tabular}

Forged round bars with a diameter of $12 \mathrm{~mm}$ were used to produce tensile specimens in accordance with DIN 50125-B 6 × 30. After machining, the tensile specimens were austenitized at $1050^{\circ} \mathrm{C} / 30 \mathrm{~min}$. A Zwick 1476 universal test machine with temperature chamber was used to determine the mechanical properties in a temperature range from $-40{ }^{\circ} \mathrm{C}$ to $200{ }^{\circ} \mathrm{C}$. Some of the specimens were work-hardened to varying degrees at RT under uniaxial loading in order to generate graded fractions of deformation-induced $\alpha^{\prime}$-martensite. On the one hand, the differently pre-strengthened tensile specimens were again subjected to the tensile test at RT. On the other hand, they were tempered in a salt bath at $450^{\circ} \mathrm{C} / 5 \mathrm{~min}$ with subsequent water quenching before being tested in a tensile test.

To characterize the microstructure, light, and scanning electron microscopic investigations have been performed on electrolytically polished samples. The focus was on the detection of $\alpha^{\prime}$-martensite and $\delta$-ferrite as well as the determination of the austenite grain size. These investigations were supplemented by EBSD and EDX measurements. The quantitative determination of the ferromagnetic phase fraction as the sum of $\alpha^{\prime}$-martensite and $\delta$-ferrite was carried out using the magnetic measurement method Metis MSAT magnetic saturation device, equipped with a Lake Shore fluxmeter. The tests to prove possible $\mathrm{M}_{\mathrm{s}}{ }^{\alpha^{\prime}}$-temperatures above and below RT were carried out using a quenching dilatometer 
with cryogenic extension measurement down to $-130{ }^{\circ} \mathrm{C}$ (DIL 805, Bähr). Changes in the ferromagnetic phase fraction in the austenitic microstructure as a result of cryogenic treatment or deformation are due to the formation of $\alpha^{\prime}$-martensite, since the ferrite fraction remains unchanged due to these stresses.

With the aid of two electrolytic test methods, the solution annealed laboratory steels were examined for their corrosion resistance at RT. The passivation was carried out in $0.05 \mathrm{M}$ sulphuric acid with a pH value of 1.4 and a $0.5 \mathrm{mV} / \mathrm{s}$ polarization speed. The resistance to pitting corrosion was determined in $0.5 \mathrm{M} \mathrm{NaCl}$ solution with a $\mathrm{pH}$ of 5.9. These current density potential curves were recorded with a polarization speed of $0.2 \mathrm{~V} / \mathrm{h}$.

\section{Results and Discussion}

\subsection{Influence of Manganese on Microstructure Formation of Austenitic Stainless Steels}

Table 1 shows the chemical composition of cast laboratory steels and spring steel 1.4310. In addition, the table contains the nickel and chromium equivalents, the calculated $\mathrm{M}_{\mathrm{s}}{ }^{\prime}$ temperatures and the stacking fault energies $\gamma_{\mathrm{SFE}}$.

Table 1 shows the varied manganese contents of the laboratory steels $6 \mathrm{Mn}$ to $2 \mathrm{Mn}$ from 6 to $2.4 \mathrm{wt} .-\%$. They are raised compared to steel 1.4310 . The nitrogen content of approximately $0.175 \mathrm{wt} .-\%$ and the remaining elements are approximately the same for the laboratory steels. Compared to spring steel 1.4310, the nickel content of the laboratory steels is reduced by approximately $48 \%$. Changes in manganese content do not cause significant changes in the stacking fault energy of austenite. As the manganese content increases, the nickel equivalents increase and the calculated $\mathrm{M}_{\mathrm{s}}{ }^{{ }^{\prime}}$-temperature decreases. This means that the austenite becomes more stable. While the chromium equivalent of the laboratory steels is approximately the same, the chromium equivalent of the steel 1.4310 is comparatively slightly increased, as the Schaeffler diagram in Figure 1 shows.

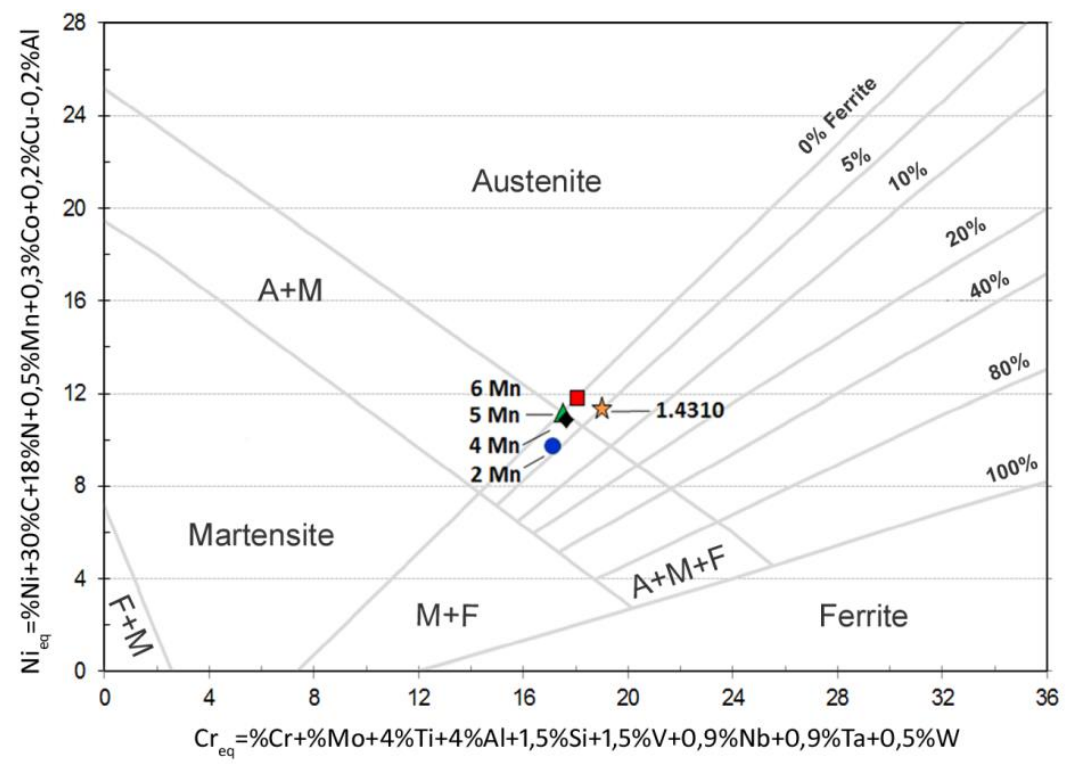

Figure 1. Position of laboratory steels and spring steel 1.4310 in the Schaeffler diagram.

In the Schaeffler diagram, the test steels are at the limits of the phase ranges for austenite, $\alpha^{\prime}$-martensite and $\delta$-ferrite. Microstructural investigations and magnetic measurements confirm that all laboratory steels have an austenitic microstructure with ferrite fractions of approximately $1 \%$ to approximately $3 \%$ in the cast state at RT. The $\delta$-ferrite fraction decrease to $\leq 1 \%$ after forging. For the steels $6 \mathrm{Mn}$ and $5 \mathrm{Mn}$, no as-quenched $\alpha^{\prime}$-martensite could be detected down to cryogenic temperature of $-196{ }^{\circ} \mathrm{C}$. On the other hand, after such a treatment, approximately $1 \%$ as-quenched $\alpha^{\prime}$-martensite 
is formed in $4 \mathrm{Mn}$ steel and approximately $13 \%$ in $2 \mathrm{Mn}$ steel. A $5 \% \alpha^{\prime}$-martensite fraction is already detectable in $2 \mathrm{Mn}$ steel at RT. This steel has the $\mathrm{M}_{\mathrm{s}}{ }^{\alpha^{\prime}}$-temperature of approximately $30^{\circ} \mathrm{C}$.

The free enthalpy differences $\Delta G^{\gamma \rightarrow \varepsilon}$ and $\Delta G^{\gamma \rightarrow \alpha^{\prime}}$ of the laboratory steels have been calculated as a function of temperature (Figure 2). They decrease with decreasing temperature below $600{ }^{\circ} \mathrm{C}$ and increase with increasing manganese content. The equilibrium temperatures $T_{0} \gamma \leftrightarrow \varepsilon$ and $T_{0} \gamma \leftrightarrow \alpha^{\prime}$ shift with increasing manganese content to lower temperatures. In the temperature range below the respective equilibrium temperature, the austenite is metastable to the $\varepsilon$ - or $\alpha^{\prime}$-phase. The austenite is affected by the chemical driving forces $\left|\Delta G^{\gamma \rightarrow \varepsilon}\right|$ and $\left|\Delta G G^{\gamma \rightarrow \alpha^{\prime}}\right|$. They increase with decreasing temperature. This increases the austenite's tendency to transform into the more stable $\varepsilon$ - or $\alpha^{\prime}$-phase. A chemical driving force $\left|\Delta G{ }^{\gamma \rightarrow \alpha^{\prime}}\right|$ of approximately $2.6 \mathrm{kJmol}^{-1}$ acts at the $\mathrm{M}_{\mathrm{s}}{ }^{\prime}$-temperature of $30^{\circ} \mathrm{C}$ on the most unstable laboratory steel $2 \mathrm{Mn}$. Similarly high chemical driving forces act below RT also on the more stable laboratory steels without $\alpha^{\prime}$-cooling martensite being detected in the steels $5 \mathrm{Mn}$ and $6 \mathrm{Mn}$ during deep-freezing. The cause for this is that below RT the almost linear temperature dependence of the chemical driving force $\left|\Delta G{ }^{\gamma \rightarrow \alpha^{\prime}}\right|$ is no longer given. With sinking temperature the chemical driving forces are reduced. The chemical driving forces $\left|\Delta G{ }^{\gamma \rightarrow \alpha^{\prime}}\right|$ decrease below the Neel temperature, which is equivalent to a stabilization of the austenite [9,31]. Such behavior is not taken into account when calculating the $\mathrm{M}_{\mathrm{S}}{ }^{\alpha^{\prime}}$-temperature in Table 1. The transformation from austenite to deformation-induced $\alpha^{\prime}$-martensite can already start above the $\mathrm{M}_{\mathrm{s}}{ }^{\alpha^{\prime}}$-temperature due to the action of external stresses. The $\mathrm{M}_{\mathrm{d}}{ }^{\alpha^{\prime}}$-temperature is the upper limit temperature at which approximately $1 \% \alpha^{\prime}$-martensite is formed due to maximum external load. Thus the $\mathrm{M}_{\mathrm{d}} \alpha^{\alpha^{\prime}}$-temperature is in a temperature range between the $\mathrm{M}_{\mathrm{s}}{ }^{\alpha^{\prime}}$-temperature and the $\mathrm{T}_{0} \gamma \leftrightarrow \alpha^{\prime}$-temperature. It is to be expected that the deformation-induced martensite fractions of the laboratory steels will be graded according to their austenite stability after maximum stress.

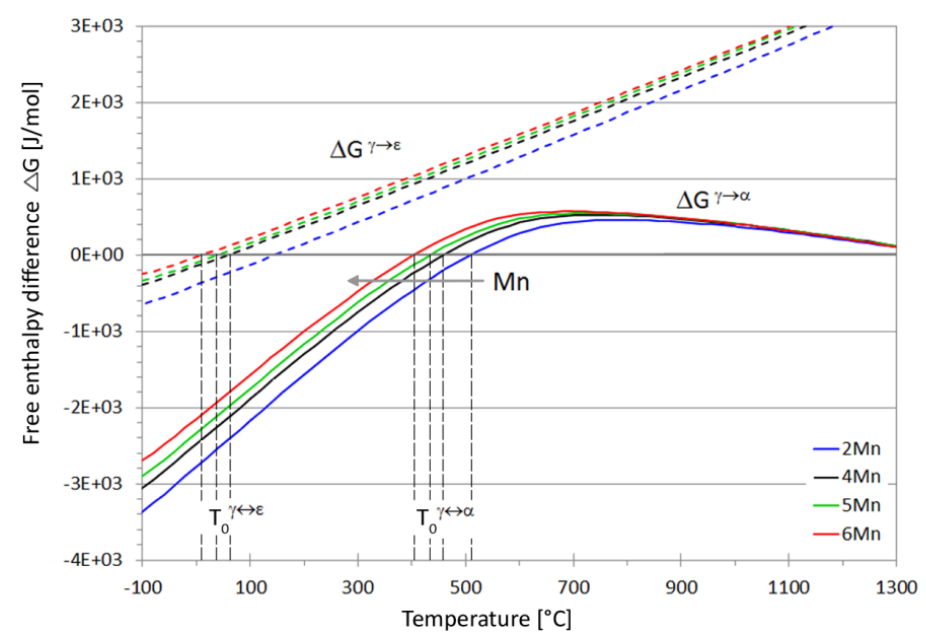

Figure 2. Free enthalpy differences $\Delta \mathrm{G}^{\gamma \rightarrow \varepsilon}$ and $\Delta \mathrm{G} \gamma \rightarrow \alpha^{\prime}$ of the laboratory steels have been calculated as a function of temperature.

According to the results in Figure 2, the formation of spontaneous $\varepsilon$-martensite cannot be ruled out. However, no spontaneous $\varepsilon$-martensite could be detected in the steels. This result can be regarded as very positive, since even small amounts of spontaneous $\varepsilon$-martensite lead to extreme embrittlement [32]. Otherwise the steels would not be suitable for spring steel.

Figure 3 shows the austenitic microstructure at RT for the hot-formed steels $2 \mathrm{Mn}, 4 \mathrm{Mn}$, and the CrNi-steel 1.4310. In addition to austenite, the $2 \mathrm{Mn}$ steel contains approximately $5 \%$ as-quenched $\alpha^{\prime}$-martensite. The $\delta$-ferrite fraction in both steels is less than $1 \%$. An average intercept length of $54 \mu \mathrm{m}$ has been determined for the steel $2 \mathrm{Mn}$ and $45 \mu \mathrm{m}$ for the steel $4 \mathrm{Mn}$. This corresponds to ASTM grain sizes $\mathrm{G}$ of 5.1 and 5.7 respectively. The steel 1.4310 is almost fully austenitic with a $\delta$-ferrite fraction of $<1 \%$. It has an average intercept length of $60 \mu \mathrm{m}(\mathrm{G}=5)$. 


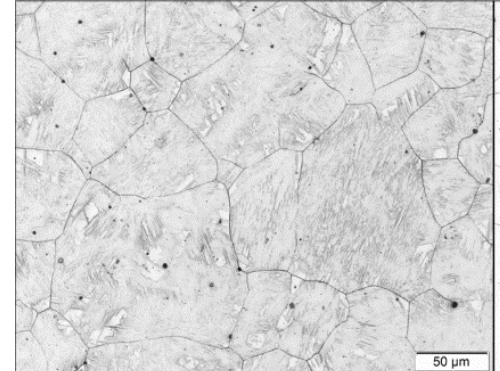

(a)

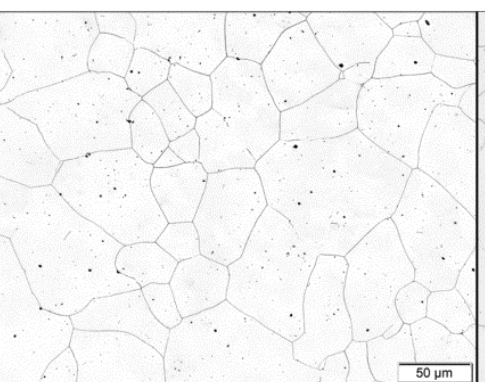

(b)

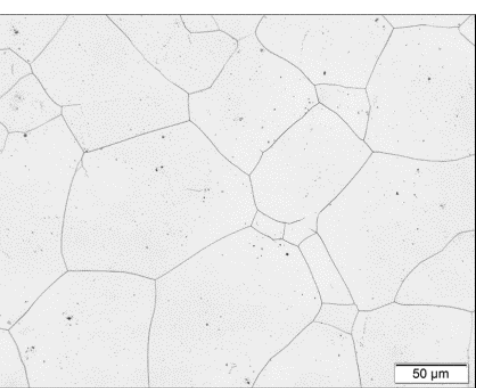

(c)

Figure 3. Light optical micrograph of austenitic steels, electrolytically etched at RT (a) $2 \mathrm{Mn}$ with 5\% as-quenched $\alpha^{\prime}$-martensite, (b) $4 \mathrm{Mn}$ without $\alpha^{\prime}$-martensite, and (c) CrNi steel 1.4310 .

\subsection{Temperature-Dependent Mechanical Properties of CrMnNiMoN Steels with TRIP/TWIP Effect}

The technical stress-strain curves of the test steels at RT and $80{ }^{\circ} \mathrm{C}$ are shown in Figure 4 . By varying the manganese content of the steels, the position of the stress-strain curves is influenced within wide limits. With increasing manganese content the fraction of $\alpha^{\prime}$-martensite decreases. The stress-strain curves are shifted to lower strength values and higher strains. The spring steel 1.4310 is classified according to its fraction of deformation-induced $\alpha^{\prime}$-martensite. The steel has the lowest ultimate tensile strength (UTS) and highest total elongation (TE) at RT, the steel 2Mn the highest UTS and lowest TE. During the tensile tests of the austenitic steels $6 \mathrm{Mn}, 5 \mathrm{Mn}$, and $4 \mathrm{Mn}$ at RT, more than $20 \% \alpha^{\prime}$-martensite was formed. These stress-strain curves show two inflection points. The inflection points mark the minimum and maximum strain hardening rates (increase in stress-strain curve) of the steels. Such behavior is caused by the deformation-induced formation of $\alpha^{\prime}$-martensite. The strong hardening of the steel is linked to the formation rate of the $\alpha^{\prime}$-martensite. The higher the fraction of $\alpha^{\prime}$-martensite per strain increase, the stronger the hardening rate is $[9,13,33]$.

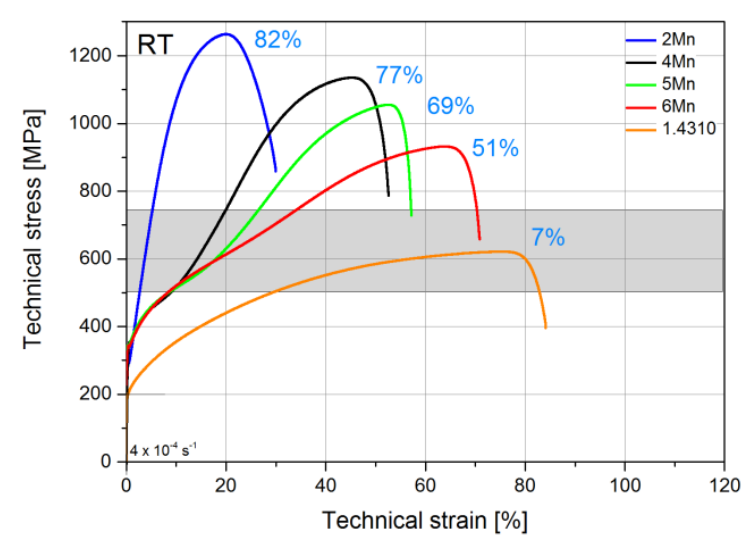

(a)

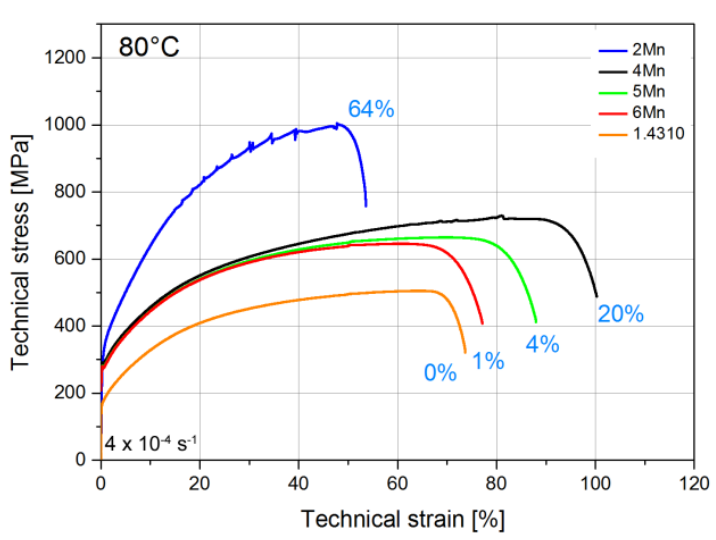

(b)

Figure 4. Technical stress-strain curves of the test steels with specification of the $\alpha^{\prime}$-martensite fraction after tensile test (a) at RT, gray - the tensile strength tolerance range according to DIN EN 10151 (2003-02) for 1.4310 and (b) at the test temperature of $80^{\circ} \mathrm{C}$.

The increase of the test temperature from $\mathrm{RT}$ to $80^{\circ} \mathrm{C}$ results in a shift of stress-strain curves to lower strengths and higher strains (Figure $4 \mathrm{~b}$ ). In addition, the deformation-induced $\alpha^{\prime}$-martensite fractions are decreasing. With regard to strain to failure, spring steel 1.4310 deviates from this behavior. Its total elongation is lower at $80^{\circ} \mathrm{C}$ than at RT. It is noteworthy that the strain properties of the test steels at $80^{\circ} \mathrm{C}$ are very different. A continuous gradation with the manganese content or the fraction of $\alpha^{\prime}$-martensite is not given. The highest elongation capacity is shown by the steel $4 \mathrm{Mn}$. In this steel approximately $20 \% \alpha^{\prime}$-martensite is produced after maximum uniaxial tensile stress. In test steels with lower and higher manganese contents and thus also higher and lower fractions of deformation-induced 
$\alpha^{\prime}$-martensite, lower strains to failure are registered. The total elongation decreases in steels containing more than $20 \% \alpha^{\prime}$-martensite and with decreasing fraction of $\alpha^{\prime}$-martensite. Such behavior is due to the TRIP/TWIP effect, as will be explained in more detail in connection with the results of the following figure.

The temperature dependencies of the yield strength and ultimate tensile strength, the maximum uniform elongation and the maximum $\alpha^{\prime}$-martensite fraction after uniaxial tensile load are shown for the test steels in Figure 5. In addition, the $\mathrm{M}_{\mathrm{d}}{ }^{\alpha^{\prime}}$-temperatures of the investigated steels were indicated in the diagrams. They chart the highest temperatures at which deformation-induced $\alpha^{\prime}$-martensite is formed under uniaxial tensile load. With decreasing temperature, the strength properties of the test steels increase the tensile strength to a greater extent than the yield strength (Figure 5a). Higher tensile strengths are registered with decreasing manganese contents. Below the respective temperature, the tensile strength increases more than above the $\mathrm{M}_{\mathrm{d}}{ }^{{ }^{\prime}}$-temperature. This is due to the hardening effect of the deformation-induced $\alpha^{\prime}$-martensite. This influence is not significantly pronounced at the yield strengths of the test steels. It can therefore be concluded for these steels that the $\alpha^{\prime}$-martensite does not influence the yield strength. The $\alpha^{\prime}$-martensite is obviously formed only in the plastic deformation range of the steels. The $2 \mathrm{Mn}$ steel is an exception to this rule. From the decrease of the yield strength

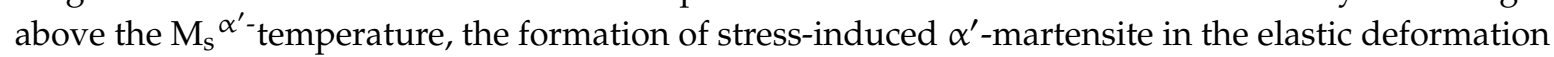
range of the austenite can be inferred [10]. The spring steel 1.4310 has the lowest strength properties over the entire temperature range. This is mainly due to the lower nitrogen and higher nickel contents and the lower fraction of deformation-induced $\alpha^{\prime}$-martensite, as shown in Table 1 and Figure $5 \mathrm{c}$.

The maximum uniform elongations are characterized by an anomalous course as a function of the test temperature (Figure $5 b$ ). As the temperature decreases, the uniform elongations increase, pass through a maximum value, and decrease. Such behavior is characteristic for metastable austenitic steels with TRIP/TWIP effect. As a consequence of the induced stacking faults and the formation of deformation-induced $\alpha^{\prime}$-martensite, plasticity effects are generated in the austenite and these overlap with the dislocation slip. The strain anomaly already starts in the temperature range above the $\mathrm{M}_{\mathrm{d}}{ }^{\alpha^{\prime}}$-temperature. In this temperature range, stacking faults with extrinsic and/or intrinsic character occur. Extrinsic stacking faults are preferred at temperatures above RT. They are nuclei for the formation of deformation twins, which cause the TWIP effect [34-36]. The more deformation-induced twins are formed as the temperature decreases the more pronounced is the TWIP effect and thus the increase in plasticity [37,38]. Only for the spring steel 1.4310 a temperature range of approximately $>160^{\circ} \mathrm{C}$ can be given, above which the twin formation comes to a standstill and obviously the climbing and sliding of dislocations dominates.

With decreasing temperature and stacking fault energy, intrinsic stacking faults are increasingly formed instead of extrinsic stacking faults [34-36]. If the thermodynamic conditions are given, hexagonal $\varepsilon$-martensite is formed. $\varepsilon$-martensite can arise spontaneously or under the effect of external tensile stresses in the elastic or plastic deformation range of austenite. If the $\varepsilon$-martensite forms in the plastic deformation area, a $\varepsilon$-TRIP effect is caused. The $\varepsilon$-TRIP effect and thus the increase in plasticity are more pronounced the higher the fraction of deformation-induced $\varepsilon$-martensite is [37,38]. $\varepsilon$-martensite, which occurs in the elastic deformation area, weakens the $\varepsilon$-TRIP effect. The plastic deformation capacity of the steel is reduced [9]. This effect obviously dominates in the temperature range below the respective strain maxima and increases with decreasing temperature. Below the $M_{d}{ }^{\alpha^{\prime}}$-temperature, the deformation-induced $\alpha^{\prime}$-martensite formation counteracts this process. The deformation-induced $\alpha^{\prime}$-martensite formation increases as the temperature decrease. It is noticeable and in accordance with the literature [25] that steels with exclusively deformation-induced $\alpha^{\prime}$-martensite formation exhibit the maximum elongation values at a fraction of approximately $20 \%-30 \% \alpha^{\prime}$-martensite. The higher the fraction of deformation-induced $\alpha^{\prime}$-martensite, the more pronounced is the increase in ultimate tensile strength [11]. The lowest UTS are therefore found in spring steel 1.4310. At the same time, this steel shows the highest elongation values in almost the entire temperature range. It is therefore concluded that the $\varepsilon$-TRIP- and the TWIP-effect must be most pronounced in this steel above RT. The 
steel $2 \mathrm{Mn}$, on the other hand, shows the lowest anomaly effect. The reason for this is the presence of as-quenched $\alpha^{\prime}$-martensite and the formation of $\alpha^{\prime}$-martensite already in the elastic deformation range of the austenite. The maximum fractions of $\alpha^{\prime}$-martensite increase with decreasing temperature and manganese content (Figure 5c).

(a)

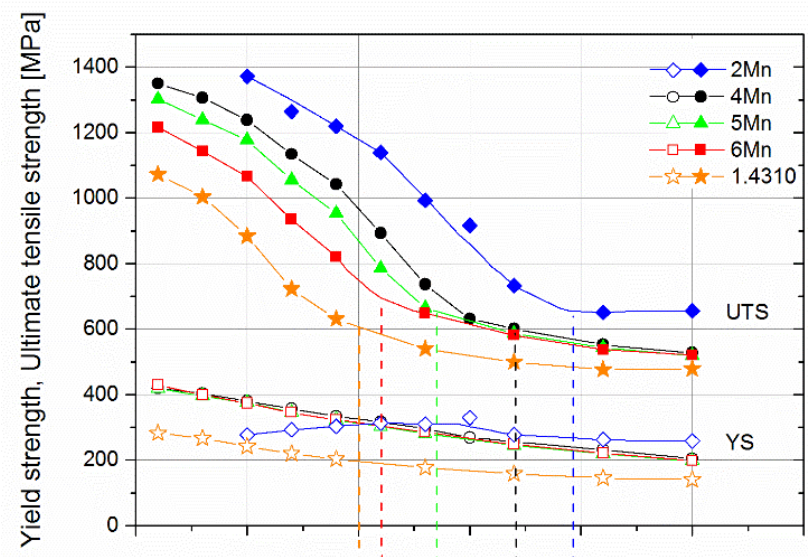

(b)

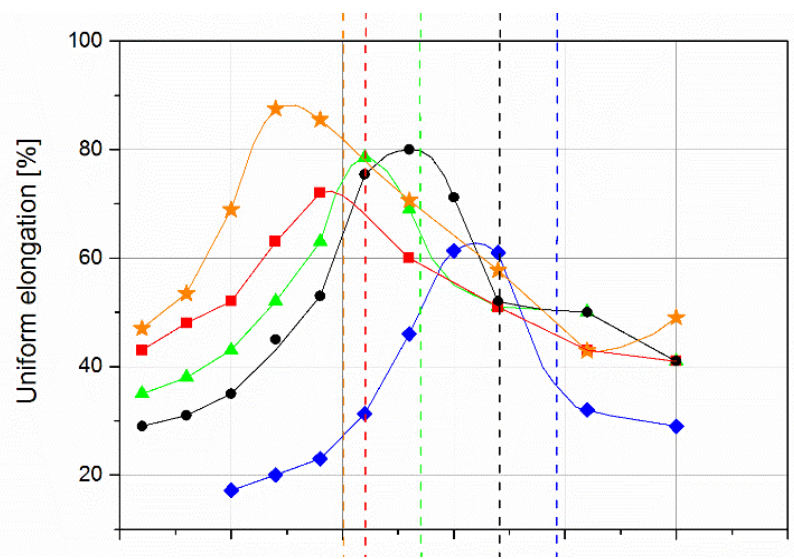

(c)

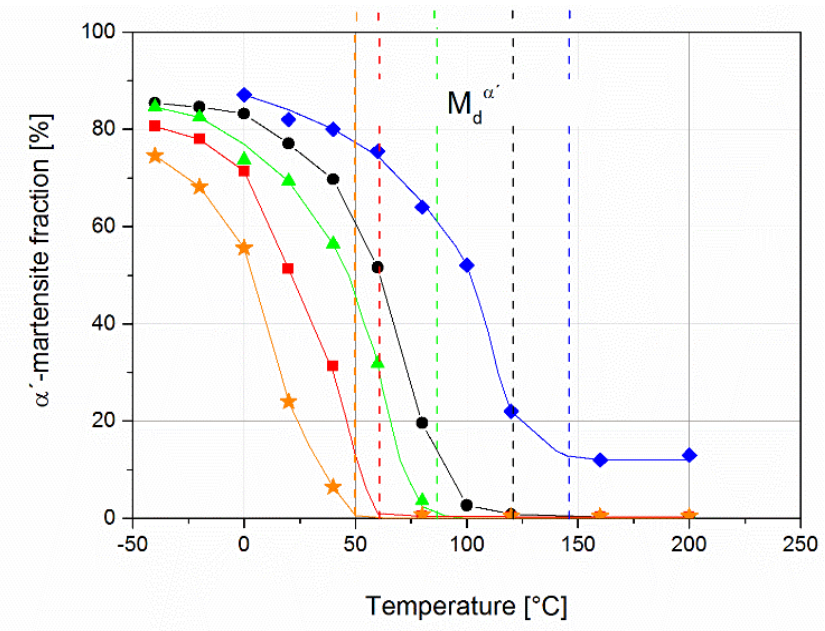

Figure 5. Temperature dependencies of (a) the yield strength and ultimate tensile strength, (b) the uniform elongation, and (c) the maximum $\alpha^{\prime}$-martensite fraction after uniaxial tensile load for the test steels.

The results in Figure 5 allow the conclusion that the tensile strength and maximum uniform elongation of high-alloy austenitic steels are a consequence of the superposition of several deformation processes, consisting of dislocation glide, twin formation (TWIP effect) and deformation-induced $\varepsilon$ - 
and $\alpha^{\prime}$-martensite formation ( $\varepsilon$ - and $\alpha^{\prime}$-TRIP effect). The individual plasticity effects have not been separated. In principle, the TRIP/TWIP effect was also observed under multi-axial compressive stress [20]. Therefore, similar results can also be expected for cold-rolling. In particular, the mechanical properties will be strongly influenced by the temperature-dependent deformation-induced microstructural transformations.

\subsection{Deformation and Partitioning Treatment of X5CrMnNiMoN16-4-4}

The 4Mn steel was selected for the subsequent tests on the basis of the results discussed above. Suitable mechanical spring and corrosion properties can be expected for this steel. At RT, the steel has an austenitic structure without spontaneous $\alpha^{\prime}$-martensite. The first deformation-induced $\alpha^{\prime}$-martensite is already formed at a temperature of $120^{\circ} \mathrm{C}$. The formation of deformation-induced $\alpha^{\prime}$-martensite at and above RT is relatively intense. The tensile strengths reach the highest values compared to laboratory steels without spontaneous martensite. The ultimate tensile strength of the $4 \mathrm{Mn}$ steel is 1134 MPa in the solution annealed state at RT with a maximum uniform elongation of $45 \%$. As a result of the deformation, $77 \%$ austenite is transformed into deformation-induced $\alpha^{\prime}$-martensite under uniaxial load. The UTS of the spring steel 1.4310 in solution annealed condition is $622 \mathrm{MPa}$ with a maximum uniform elongation of $75 \%$. The microstructure contains approximately $24 \%$ deformation-induced $\alpha^{\prime}$-martensite. The product of tensile strength and maximum uniform elongation can be used as a measure of cold formability. It amounts to $46,650 \mathrm{MPa} \cdot \%$ for the steel 1.4310 and $51,030 \mathrm{MPa} \cdot \%$ for the steel $4 \mathrm{Mn}$. This corresponds to an increase of $9 \%$.

In addition, in the temperature range between $40^{\circ} \mathrm{C}$ and $120^{\circ} \mathrm{C}$, a distinct TRIP/TWIP effect is registered. If cold rolling of spring steel strip is preferably performed in this temperature range, the plasticity gain as a result of the TRIP/TWIP effect during rolling can be exploited technologically.

The results shown below refer to specimens which have been work-hardened to varying degrees at RT. The samples were subjected to true tensile stresses of $1135 \mathrm{MPa}, 1290 \mathrm{MPa}$, and $1420 \mathrm{MPa}$. Figure 6 shows the flow curve of the $4 \mathrm{Mn}$ steel with the three tensile stresses drawn in and the associated true strains.

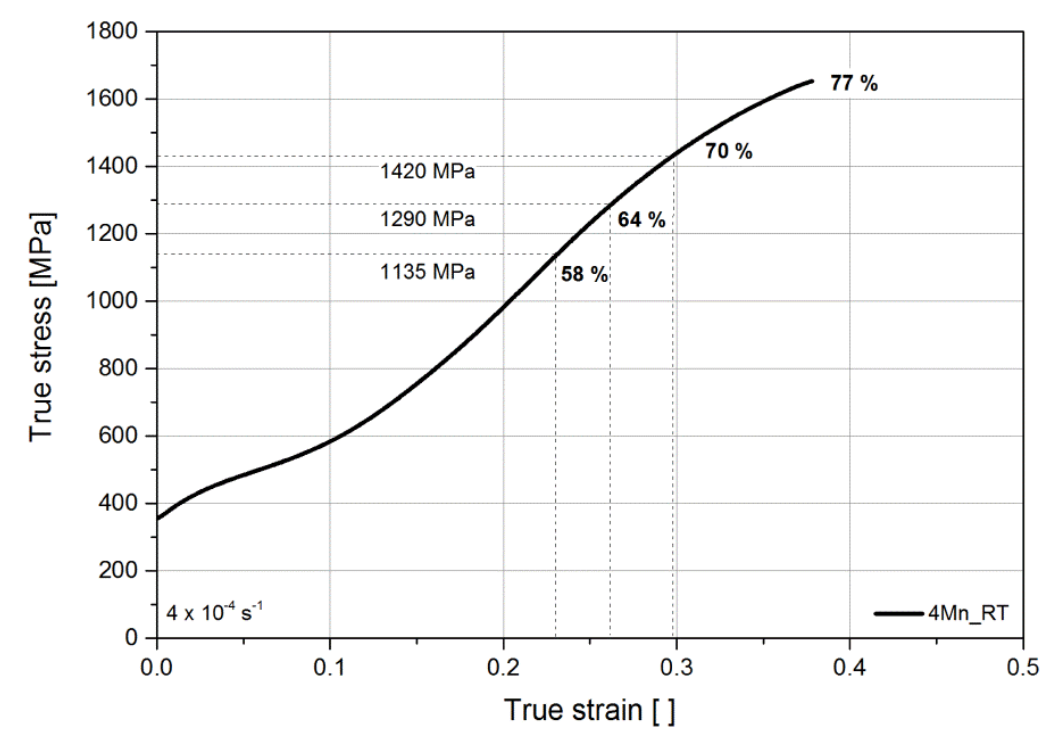

Figure 6. Flow curve at room temperature (RT) for steel $4 \mathrm{Mn}$ with specification of the martensite fractions of graded true stress states and after the tensile test.

The course of the flow curve is marked by two inflection points. The fraction of $\alpha^{\prime}$-martensite increases with increasing tensile stress. Due to the stated true tensile stresses, $58 \%, 64 \%$, and $70 \%$ austenite were transformed into deformation-induction $\alpha^{\prime}$-martensite. These martensite components 
are retained during relief and cause a desired increase in strength during reloading in the tensile test (Figure 7).

(a)

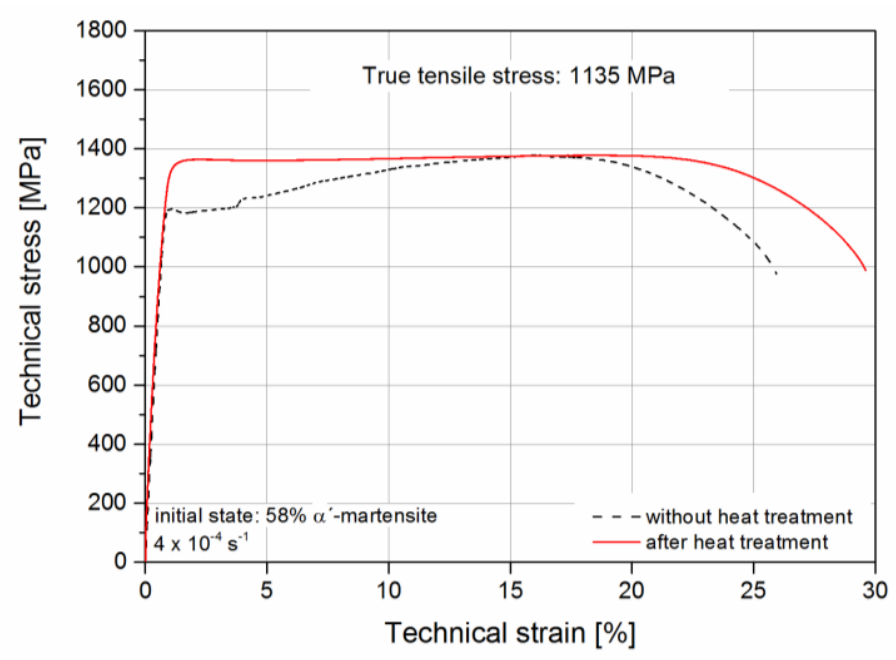

(b)

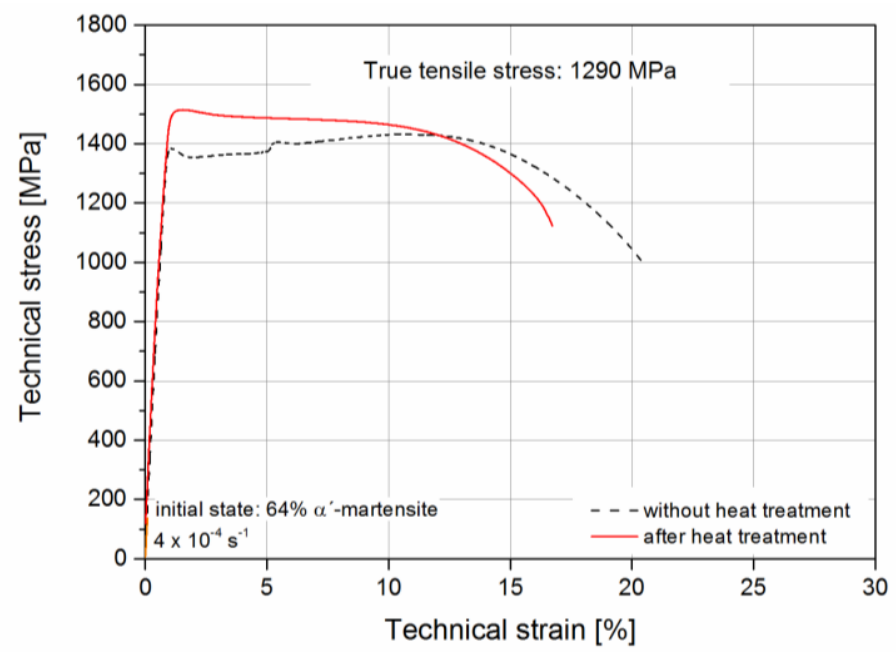

(c)

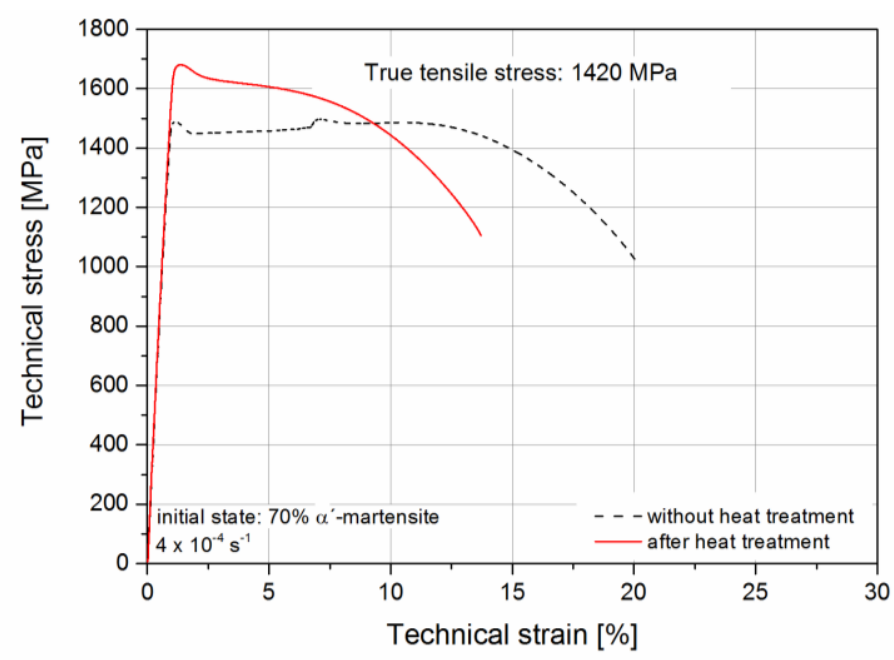

Figure 7. Technical stress-strain curves of work-hardened steel $4 \mathrm{Mn}$ after application of a true tensile stress at RT of (a) $1135 \mathrm{MPa}$, (b) $1290 \mathrm{MPa}$, and (c) $1420 \mathrm{MPa}$ without and with heat treatment at $450{ }^{\circ} \mathrm{C} / 5 \mathrm{~min} /$ water. 
The work hardening, the $\alpha^{\prime}$-martensite fraction and the annealing treatment influence the stress-strain curves. In specimens without heat treatment, higher yield strengths and tensile strengths are registered with increasing true tensile stress and thus increasing fractions of $\alpha^{\prime}$-martensite. Both stress values are approaching. However, the tensile strengths are below the required minimum tensile strength for spring band of $1700 \mathrm{MPa}$. The maximum uniform elongation and the total elongation decrease with increasing work hardening of the specimens before the tensile test. The total elongations reach $\geq 20 \%$ in all three work hardening stages, so that there is a relatively high plasticity reserve against fracture for all microstructural states. The $\alpha^{\prime}$-martensite fractions increase to $77 \%$ up to the maximum uniform elongation. Such a martensite fraction was also determined in comparable tensile specimens without pre-strengthening.

The yield strengths (YS) are increased by $80 \mathrm{MPa}, 98 \mathrm{MPa}$, and $184 \mathrm{MPa}$, respectively, by short-time annealing. The increase in strength rises with advancing pre-straining. This trend is also reflected in the tensile strengths. The tensile strengths increase from $1377 \mathrm{MPa}$ over $1514 \mathrm{MPa}$ to $1679 \mathrm{MPa}$. With increasing pre-straining, the YS and the UTS approach more closely. Contrary to this, the yield strength of the heat-treated tensile specimens with the lowest pre-straining increases to the level of the tensile strength of non-heat-treated tensile specimens, as Figure 7a shows. In this case, the total elongation is simultaneously increased by $4 \%$ to $29 \%$. The $\alpha^{\prime}$-martensite fractions of the work-hardened and heat-treated specimens do not increase under tensile stress.

In investigations on cast alloys of similar chemical composition, such an increase in strength through heat treatment is obviously due to the preferred formation of nanometer-sized precipitates in the supersaturated $\alpha^{\prime}$-martensite [13,28]. The nitrogen and carbon diffusion from the martensite and the enrichment of the atoms at the martensite/austenite phase boundaries superimpose this process. This stabilizes the retained austenite. The austenite remains stable under subsequent tensile stress and does not transform into deformation-induced $\alpha^{\prime}$-martensite. The elongation of the heat-treated specimens is obviously positively influenced by twin formation. The twin formation should be more pronounced in less strain-hardened samples. The required UTS for spring steel strip of $1700 \mathrm{MPa}$ is narrowly failed in the most strongly strain-hardened tensile test specimens after short-time annealing. There is a high plasticity reserve until the fracture. It decreases with increasing pre-hardening. The required strain to failure for spring steel strip of $\geq 2 \%$ is far exceeded for all strength levels with and without heat treatment.

From the results it can be concluded that true tensile stresses greater than $1420 \mathrm{MPa}$ must be invested to achieve the minimum tensile strength of $\geq 1700 \mathrm{MPa}$. Stronger work hardening can be achieved by multi-axial load.

\subsection{Corrosive Properties of Mn-Containing Austenitic Stainless Steels}

The corrosive resistance of manganese-containing laboratory steels was compared with the properties of CrNi steel 1.4310 on the basis of their passivation behavior and their resistance to pitting corrosion. The passivation behavior in 0.05 molar sulfuric acid can be read from Figure 8 using the current density potential curves.

In the passive range the current densities of the laboratory steels are lower than the current density of the spring steel 1.4310. This is an indication of a denser formation of the passivation layer in the case of laboratory steels. For the steel $4 \mathrm{Mn}$ the current density is $2 \cdot 17 \cdot 10^{-3} \mathrm{~mA} / \mathrm{cm}^{2}$ at $400 \mathrm{mV}$. The breakthrough potential for all test steels is almost constant $860 \mathrm{mV}$. In addition, the laboratory steels show a pronounced repassivation at increased potentials. This high corrosion resistance is decisively caused by the increased nitrogen and molybdenum content of the laboratory steels. Compared to the other laboratory steels, $2 \mathrm{Mn}$ steel has an increased current density. This behavior is probably due to the presence of spontaneous $\alpha^{\prime}$-martensite. In addition, it can be concluded from the results that the manganese content of the steel has no significant influence on the formation of the passivation layer. 


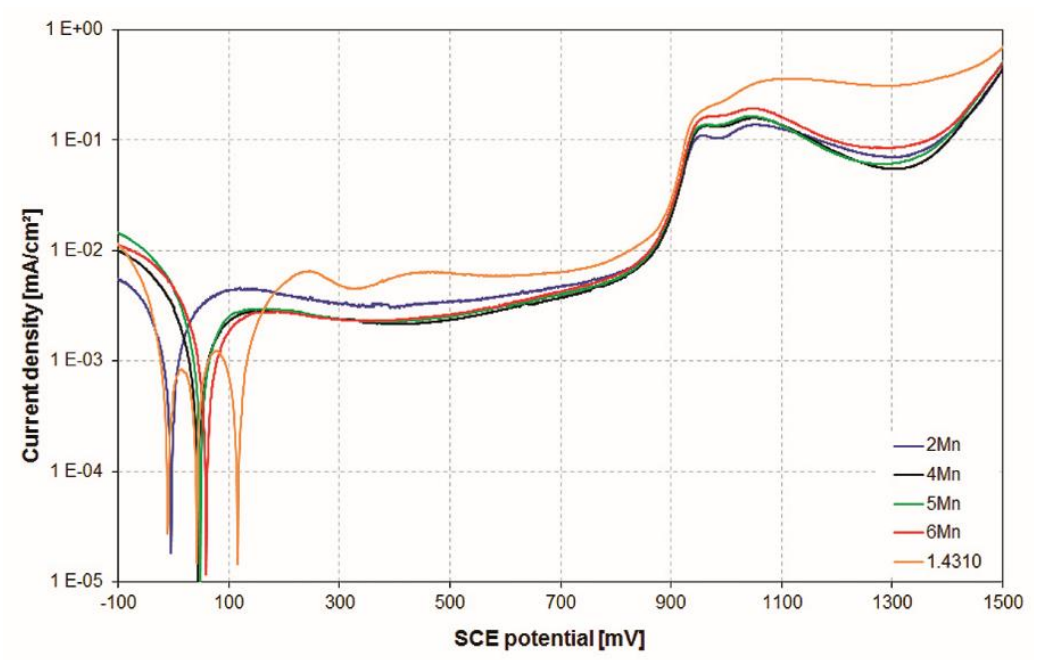

Figure 8. Current density potential curves for the austenitic microstructure states of the test steels for passivation behavior in 0.05 molar sulfuric acid.

Figure 9 shows the current density potential curves for the test steels in 0.5 molar NaCl-solution. Characteristic of the resistance to pitting corrosion is the breakthrough potential. The higher this potential is, the higher the resistance to pitting corrosion.

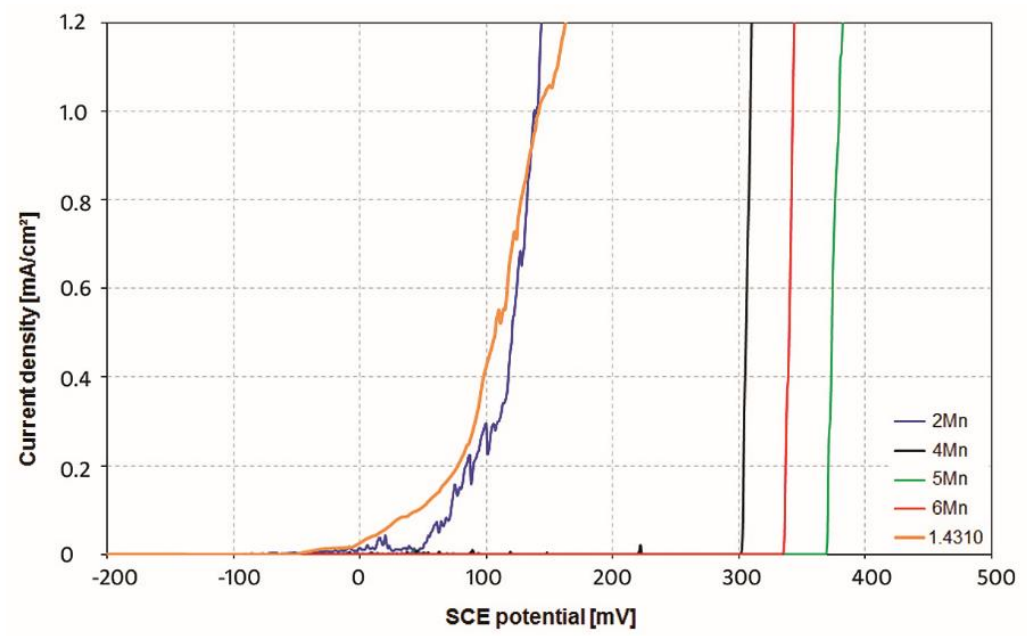

Figure 9. Current density potential curves for the un-deformed, austenitic microstructural states of the test steels in 0.5 molar $\mathrm{NaCl}$-solution.

The lowest breakthrough potential was observed for the steels 1.4310 and $2 \mathrm{Mn}$. The 1.4310 steel has an almost fully austenitic structure. Due to its lower contents of nitrogen and molybdenum, it is more susceptible to pitting corrosion than the austenitic laboratory steels. The Pitting Resistance Equivalent rises with increasing contents of chromium, molybdenum, and nitrogen [5]. Manganese has no significant influence on the pitting corrosion behavior. The Pitting Resistance Equivalent of the laboratory steels differ only slightly from each other with 23.4 to 24.0 , which is due to slightly varying chromium and nitrogen contents. In contrast to the steels $4 \mathrm{Mn}, 5 \mathrm{Mn}$, and $6 \mathrm{Mn}$ the steel $2 \mathrm{Mn}$ contains $5 \%$ spontaneous $\alpha^{\prime}$-martensite. The $\alpha^{\prime}$-martensite has the same chemical composition as the austenitic matrix. However, it has an increased dislocation density, which is considered the cause for the reduction of the pitting resistance. The steels $4 \mathrm{Mn}, 5 \mathrm{Mn}$, and $6 \mathrm{Mn}$ show high breakthrough potentials of $300-370 \mathrm{mV}$. 


\section{Summery and Conclusions}

The microstructure and the mechanical and corrosive properties of four laboratory steels and the spring steel 1.4310 were presented, discussed and compared. The laboratory steels are nickel-reduced austenitic spring steels of the type $\mathrm{X} 5 \mathrm{CrMnNiMoN} 16-\mathrm{x}-4$. These steels have manganese contents of approximately $2 \%$ to $6 \%$ with approximately constant nitrogen contents of $0.175 \%$. All test steels have a metastable austenitic microstructure. The stacking fault energies $\gamma_{\mathrm{SFE}}$ of the manganese content laboratory steels are almost constant and slightly higher than the stacking fault energy of steel 1.4310.

With increasing manganese content of the steels, the $\mathrm{M}_{\mathrm{s}}{ }^{\prime}$ - and $\mathrm{M}_{\mathrm{d}}{ }^{\alpha^{\prime}}$ - temperatures decrease and the $\alpha^{\prime}$-martensite content reduces. Regardless of the manganese content, the highest maximum uniform elongation is observed above room temperature with a deformation-induced $\alpha^{\prime}$-martensite content of $20 \%-30 \%$. The increase in plasticity is a result of the TRIP/TWIP effect. It can be used technically to achieve higher thickness reductions during the cold-rolling of strip. This offers the potential to reduce the necessary number of intermediate annealing during cold forming.

The more deformation-induced $\alpha^{\prime}$-martensite is formed, the more the tensile strength of the steels increases. The highest tensile strength in solution annealed condition is achieved in $2 \mathrm{Mn}$ steel. However, this steel is susceptible to corrosion. For this reason, $4 \mathrm{Mn}$ steel was selected for further investigations into spring steel production. Compared to the spring steel 1.4310, the steel $4 \mathrm{Mn}$ shows a higher passivation behavior and a higher resistance to pitting corrosion. The hot-formed laboratory steel $4 \mathrm{Mn}$ has increased strength compared to 1.4310 spring steel due to the high deformation-induced $\alpha^{\prime}$-martensite fraction and nitrogen content. In addition, $4 \mathrm{Mn}$ steel has the most pronounced TRIP/TWIP effect above RT under tensile stress. A short-term heat treatment following the forming process (deformation and partitioning treatment) results in a further increase in the yield strength and the ultimate tensile strength. There is still sufficient plasticity reserve until fracture. Although the $4 \mathrm{Mn}$ steel, after being subjected to uniaxial stress in the short-time annealed state, just misses the required tensile strength of $\geq 1700 \mathrm{MPa}$, it is considered that, compared to other laboratory steels, it is the most suitable steel for the production of $0.2 \mathrm{~mm}$ spring steel strip on an industrial scale.

The test results serve as the basis for the production of spring steel, the further processing into spring steel strip on a laboratory scale up to the production of $0.2 \mathrm{~mm}$ spring steel strip on an industrial scale. Although other forces act under cold rolling conditions than in tensile tests, the occurrence of a TRIP/TWIP effect above RT is also expected. From the TRIP/TWIP properties in the tensile test, important conclusions can therefore be drawn regarding the determination of the most suitable forming conditions during cold-rolling.

Author Contributions: As director of the Institute of Iron- and Steel Technology of the TU Bergakademie Freiberg, $\mathrm{O} . \mathrm{V}$. is responsible for the project management including the coordination of the planning and execution of research activities. A.W. and C.S. worked out the goals of the project significantly and were able to win the Auerhammer Metallwerk $\mathrm{GmbH}$ as an industrial partner for the transfer project. Knowledge from earlier projects about the industrial production of austenitic stainless CrMnNiMoN-steel strip (BMBF 033R073B) under the direction of A.W. and C.S., and from basic research about the development of stainless austenitic cast steels within the framework of the CRC 799 (M.W., O.V.) could be used to develop the concept and to define the test methods. The experiments listed in the paper were carried out by C.S. and/or under her direction. T.K. was responsible for the steel analysis of the melts/laboratory steels and the reference material as well as the heat treatment of the samples at the institute. The published results were visualized and compiled by C.S. in close cooperation with A.W. and M.W.. All authors have contributed to the publication of this article.

Funding: This research was funded by German Research Foundation (DFG) within the framework of the Collaborative Research Center 799 (CRC 799).

Acknowledgments: We thank our partners in the transfer project, the Institute of Metal Forming and Auerhammer Metallwerk GmbH. Special thanks go to Dr.-Ing. Michel for his project support, to Schade for his support in carrying out the tensile tests and to the technical staff of the Institute of Iron and Steel Technology at the TU Bergakademie Freiberg.

Conflicts of Interest: The authors declare no conflict of interest. 


\section{References}

1. DIN EN 10151:2003-02. Federband aus nichtrostenden Stählen. 2003. 77.140.25. Available online: https: //www.en-standard.eu/ (accessed on 14 June 2019).

2. Padilha, A.F.; Plaut, R.L.; Rios, P.R. Annealing of Cold-worked Austenitic Stainless Steels. ISIJ Int. 2003, 43, 135-143. [CrossRef]

3. Trillo, E.A.; Beltran, R.; Maldonado, J.G.; Remoro, R.J.; Murr, L.E.; Fisher, W.W.; Advani, A.H. Combined Effects of Deformation (Strain and Strain State), Grain Size, and Carbon Content on Carbide Precipitation and Corrosion Sensitization in 304 Stainless Steel. Mater. Charact. 1995, 35, 99-112. [CrossRef]

4. Mola, J.; De Cooman, B.C. Quenching and Partitioning (Q\&P) Processing of Martensitic Stainless Steels. Metall. Mat. Trans. A 2013, 44, 946-967.

5. Gümpel, P.; Ladwein, T.; Michel, E.; Strom, F.H. Wirksumme Loch- und Spaltkorrosion. TEW-Tech. Ber. 14 1988, 12-25.

6. Nyström, M.; Lindstedt, U.; Karlsson, B.; Nilsson, J.O. Influence of nitrogen and grain size on deformation behaviour of austenitic stainless steels. Mater. Sci. Technol. 1997, 7, 560-567. [CrossRef]

7. Degallaix, J.; Foct, J.; Hendry, A. Mechanical behaviour of high-nitrogen stainless steels. Mater. Sci. Technol. 1986, 2, 946-950. [CrossRef]

8. Schröder, C.; Weiß, A.; Volkova, O. Development of a new stainless austenitic CrMnNi steel using TRIP/TWIP effect for a high cold formability. Materwiss. Werkstofftech. 2018, 49, 577-590. [CrossRef]

9. Weiß, A.; Gutte, H. Spannungs- und verformungsinduzierte Martensitbildung in metastabilen austenitischen CrNi-Stählen. Postdoctoral Thesis, TU Bergakademie Freiberg, Freiberg, Germany, 2011.

10. Jahn, A. Einfluss der Martensitbildung auf die mechanischen Eigenschaften von ein- und Einfluss der Martensitbildung auf die mechanischen Eigenschaften von ein- und mehrphasigen gegossenen und warmgewalzten Cr-Mn-Ni Stählen gewalzten Cr-Mn-Ni Stählen. Ph.D. Thesis, TU Bergakademie Freiberg, Freiberg, Germany, 2011.

11. Weiß, A.; Gutte, H.; Mola, J. Contributions of $\varepsilon$ and $\alpha^{\prime}$ TRIP Effects to the Strength and Ductility of AISI 304 (X5CrNi18-10) Austenitic Stainless Steel. Metall. Mat. Trans. A 2016, 47, 112-122. [CrossRef]

12. Wendler, M.; Weiß, A.; Krüger, L.; Mola, J.; Franke, A.; Kovalev, A.; Wolf, S. Effect of Manganese on Microstructure and Mechanical Properties of Cast High Alloyed CrMnNi-N Steels. Adv. Eng. Mater. 2013, 15, 558-565. [CrossRef]

13. Wendler, M. Metastabile austenithaltige Cr-Mn-Ni-Stahlgusslegierungen mit C und N, deren Erzeugung, Werkstoffverhalten und Festigkeitssteigerung. Ph.D. Thesis, TU Bergakademie Freiberg, Freiberg, Germany, 2017.

14. Eichelmann, G.H.; Hull, F.C. The effect of composition on the temperature of spontaneous transformation of austenite to martensite in 18-8 type stainless steel. Trans. ASM 1953, 77-104.

15. Pickering, F.B. Physical Metallurgy and the Design of Steel; Applied Science Publishers: New York, NY, USA, 1978.

16. Schaeffler, A.L. Constitution diagram for stainless steel weld metal. Metall. Prog. 1949, 680.

17. Weiß, A.; Gutte, H.; Radtke, M.; Scheller, P.R. Rustproof austenitic cast steel, Method of production and use thereof. WO2008009722, 24 January 2008.

18. Nam, A.; Turdimatov, M.; Kawalla, R.; Prahl, U. Inter-Pass Softening Behavior of Fe-16Cr- $\mathrm{x}$ Mn-4Ni-0.05C-0.17N Steel. Adv. Eng. Mater. 2019, 21, 1800692. [CrossRef]

19. Nam, A.; Turdimatov, M.; Kawalla, R.; Prahl, U. The Kinetics of Dynamic Recrystallization of Fe-16Cr-xMn-4Ni-0.05C-0.17N Steel. Steel Res. Int. 2019, 90, 1800309. [CrossRef]

20. Frehn, A.; Franke, A.; Bleck, W.; Weiß, A. Bedeutung der Umformtemperatur und -geschwindigkeit bei der Blechumformung austenitischer Stähle. UTF Sci. 2001, III, 8-12.

21. Weiss, A.; Lehnert, W.; Gutte, H.; Scheller, P.R. Verbesserung der Kaltumformbarkeit austenitischer CrNi-Stähle durch Nutzung des TRIP-Effektes. ATZ-Automob. Z. 2005, 1, 68-72. [CrossRef]

22. Lehnert, W.; Weiß, A. Verfahren zur Herstellung rißfreier kaltumgeformter Teile aus korrosionsbeständigen metastabilen austenitischen Stählen. DE10052744A1, 2 May 2002.

23. Müller-Bollenhagen, $C$. Verformungsinduzierte Martensitbildung bei mehrstufiger Umformung und deren Nutzung zur Optimierung der HCF- und VHCF-Eigenschaften von austenitischem Edelstahlblech. Ph.D. Thesis, TU Siegen, Siegen, Germany, 2011. 
24. Schröder, C.; Weiß, A. Feinblech für die Herstellung von Wärmetauschern. Konstruktion 2016, IW12-IW15.

25. Weiss, A.; Lehnert, W.; Franke, A. Bessere Nutzung der Potentiale austenitischer CrNi-Stähle. Blech Rohre Profile 2001, 6, 55-56.

26. Schröder, C.; Weiß, A. Nichtrostender Austenitischer CrMnNiMoN-Stahl mit TRIP/TWIP-Eigenschaften für Feinblech; TU Bergakademie Freiberg FFH B377: Freiberg, Germany, 2018; pp. 118-128. ISBN 978-3-86012-583-0.

27. Radajewski, M.; Eckner, R.; Decker, S.; Wendler, M.; Krüger, L. Influence of Temperature and Strain Rate during Thermomechanical Treatment of a Metastable Austenitic TRIP Steel Compacted by SPS/FAST. Adv. Eng. Mater. 2019, 21, 1800617. [CrossRef]

28. Wendler, M.; Ullrich, C.; Hauser, M.; Krüger, L.; Volkova, O.; Weiß, A.; Mola, J. Quenching and partitioning (Q\&P) processing of fully austenitic stainless steels. Acta Mater. 2017, 133, 346-355.

29. Mola, J.; De Cooman, B.C. Quenching and partitioning processing of transformable ferritic stainless steels. Scripta Mater. 2011, 65, 834-837. [CrossRef]

30. Dai, Q.X.; Wang, A.D.; Cheng, X.N.; Luo, X.M. Stacking fault energy of cryogenic austenitic steels. Chin. Phys. 2002, 596-600.

31. Hauser, M.; Wendler, M.; Weiß, A.; Volkova, O.; Mola, J. On the critical driving force for deformation-induced $\alpha^{\prime}$-martensite formation in austenitic Cr-Mn-Ni Steels. Adv. Eng. Mater. 2019, 21, 1800676. [CrossRef]

32. Lepistö, T.; Kettunen, P. Embrittlement caused by epsilon-martensite in stainless steels. Scand. J. Metall. 1978, $71,71-76$.

33. Talonen, J.; Nenonen, P.; Pape, G.; Hänninen, H. Effect of strain rate on the strain-induced $\gamma \rightarrow \alpha^{\prime}$-martensite transformation and mechanical properties of austenitic stainless steels. Metall. Mat. Trans. A 2005, 36A, 421-432. [CrossRef]

34. Olson, G.B.; Cohen, M. A general mechanism of martensitic nucleation: Part I. General concepts and the FCC $\rightarrow$ HCP transformation. Metall. Mat. Trans. A 1976, 7, 1897-1904.

35. Olson, G.B.; Cohen, M. A general mechanism of martensitic nucleation: Part II. FCC $\rightarrow$ BCC and other martensitic transformations. Metall. Mat. Trans. A 1976, 7, 1905-1914.

36. Olson, G.B.; Cohen, M. A general mechanism of martensitic nucleation: Part III. Kinetics of martensitic nucleation. Metall. Mat. Trans. A 1976, 7, 1915-1923. [CrossRef]

37. Tamura, I. Deformation-induced martensitic transformation and transformation-induced plasticity in steels. Mater. Sci. Eng. A 1982, 245-253. [CrossRef]

38. Talonen, J. Effect of strain-induced $\alpha^{\prime}$-martensite transformation on mechanical properties of metastable austenitic stainless steels. Ph.D. Thesis, Helsinki University of Technology, Helsinki, Finland, 2007. 